\title{
Variation in nutrient composition of crop contents of scavenging local chickens in North Central Nigeria
}

\author{
O.M. Momoh, J.O.Egahi*, P.O.Ogwuche and V.E.Etim \\ Department of Animal Breeding and physiology \\ University of Agriculture Makurdi, Nigeria \\ ABSTRACT
}

\begin{abstract}
A total of 154 free ranging local chicken comprising 54 hens and 100 growers of mixed sexes randomly sampled from the rural flock of Beetse and Ahua communities in North Central Nigeria were used in this study to evaluate the effect of season on crop contents of the birds. The chickens were carefully stunned, slaughtered, scalded and eviscerated at the end of the day's scavenging hours for physical examination and subsequent proximate analysis of the crop contents. Crop contents were visually categorized, oven dried to a constant weight at $70^{\circ} \mathrm{C}$, milled and analyzed for proximate values. Cereal grains, kitchen wastes, green forage and insects/worms were the main crop contents and their composition varied with season and type of bird. Proximate results of crop contents show that the nutritional status of the scavenging birds fell short of requirements for profitable production. Therefore, a deliberate and regular supplementation of feed based on the available scavenging feed resources is recommended for any meaningful profitable production by these class of birds.
\end{abstract}

Keywords: Crop contents, nutrients, chickens

\section{INTRODUCTION}

The Nigerian local chickens constitute about $80 \%$ of the total poultry population in the country (Sonaiya, 1997). As in other African countries, they are under the traditional management system where they are left to scavenge for their nutritional needs with little or no feed supplementation or any elaborate housing. Thus, the performance of these birds vary from one place to another depending on the availability of scavenging feed resources (SFR) which may include worms, insects, seeds, green leaves, and other plant materials found in household yards (Mwaluanya et al 2002). Grains and household food -left- over are occasional sources of supplementary feed (Ologhobo, 1990).

In local chicken nutrition, the quantity and quality of the scavenged feed is not known (Roberts and Gunaratne, 1992). This makes the task of improving their nutrition a difficult one. In general, the plane of nutrition of the local chickens is low and varies with season of the year (Gunaratne et al, 1993; Dessie, 1996). It also varies with the locality and to some extent by the foraging habit which may differ with the type of bird (Mwalusanya et al, 2002).

A conscious effort at improving the nutritional status of the local chicken population through feed supplement must begin with knowing the requirements of the birds(Huchzermeyer, 1973) and also evaluating the nutrient content of SFR available to the local chicken population. A direct evaluation of the nutrient contents of available SFR is often cumbersome. An indirect method is assessment of the nutritional status of the crop contents of the scavenging chickens. This study was therefore undertaken to evaluate the nutrient status of SFR of the local chicken population of North central Nigeria in two different seasons.

\section{MATERIALS AND METHODS}

This study was conducted in Makurdi Benue State in North Central Nigeria. Makurdi is located between latitude $7^{0} 21^{1}$ to $8^{0} \mathrm{~N}$ and Longitude $8^{0} 20^{1}$ to $9^{0} \mathrm{E}$ with a low altitude ( $97 \mathrm{~m}$ above sea level) and an annual rainfall range of $1250 \mathrm{~mm}-1750 \mathrm{~mm}$ and a moderate relative humidity of $52.2 \%$ - 69.1\%. Makurdi experiences two seasons; (dry and rainy) between April-Sept and Oct-March respectively. Each of these seasons can be subdivided into Early rainy season (April - June), Late rainy season (July September), Early dry season (October - December) and Late dry season (January - March).

Local Chicken Population: The local chicken population studied comprised of indigenous scavenging flocks of two adjacent communities of Beetse and Ahua. The communities are essentially agrarian; cultivating food crops as rice, maize, millet, sorghum, cowpea groundnuts, cassava, potatoes and 
yams. Chicken, ducks, sheep,goats and pigs are common livestock kept.

The chickens scavenge during the day and roost in kitchens, roof tops and tree tops in the night. Supplementary feeding mostly with grains is occasionally provided in the mornings.

Experimental Birds and Procedure: The experimental birds comprising of 54 hens, 50 males and 54 female growers were randomly sampled from different parts of the communities. The hens were not less than 26 weeks of age, i.e. having gone through one laying cycle while the growers being of mixed sexes aged 3-5 months. Sampling was done twice for each of four seasons namely Early rainy (April June), Late rainy (July - September), Early dry (October - December) and Late dry (January March) in the year 2007. Sampling was usually between the hours of $6.00-7.00 \mathrm{pm}$ local time which was presumably the last hours of scavenging.

The sampled birds were carefully stunned, slaughtered, scalded and eviscerated in the laboratory. Full crops were taken and weighed on an electronic balance. Feed items in the crop of individual birds were classified, weighed and oven dried at $70^{\circ} \mathrm{C}$ to a constant weight. The oven dried crop contents were milled and analyzed for proximate composition as out lined by AOAC. (1990) procedures. Calcium $(\mathrm{Ca})$ and phosphorus $(\mathrm{P})$ were determined by atomic absorption and spectrophotometry, respectively (FAO, 1980). The true metabolizable energy of the dry contents was estimated by the procedure of Wiseman (1987).
Statistical Analysis: Data collected were analysed using the General Linear Models (GLM) procedure of SAS (1999) based on the model:

$\begin{array}{lll}\mathrm{Y}_{\mathrm{ijk}} & = & \mu+\mathrm{ai}+\mathrm{sj}+(\mathrm{as})_{\mathrm{ij}}+\mathrm{e}_{\mathrm{ijk}} \\ \mathrm{Where} & \\ \mathrm{Y}_{\mathrm{ijk}} & = & \text { An observation for a given variable } \\ \mu & = & \text { overall mean } \\ \mathrm{ai} & = & \text { effect of the } \mathrm{i}^{\text {th }} \text { age of the bird }(\mathrm{I}=1,2) \\ \mathrm{sj} & = & \text { effect of the } \mathrm{j}^{\text {th }} \text { season }(\mathrm{j}=1,2) \\ (\mathrm{as})_{\mathrm{ij}} & = & \text { effect of interaction between age of bird } \\ & & \text { and season of the year. } \\ \mathrm{e}_{\mathrm{ijk}} & = & \text { residual random error. }\end{array}$

\section{RESULTS}

The physical composition of the chicken's crop contents in the different seasons and by age of birds is presented in Table 1. Through physical examination, the crop contents were categorized into cereal grains, green forages, insects/worms, kitchen wastes and constituents made up of melon seeds, peels and unidentified substances, classified as others. These crop contents varied with season and age of bird. However, the green forage component of the crop contents was highest during the late dry season as well as higher for layers and growers. Similarly, green forages were more predominant $(P<0.05)$ in the crop contents during early rainy season than all the other seasons. Insects/worms formed significant $(P<0.05)$ component of the crop of birds, during early and late rainy seasons as compared to the early and late dry seasons. They were also found more $(P<0.05)$ in the crop of layers than growers. Kitchen waste had similar trend with insects/worms with respect to season and age of bird.

Table 1: Physical composition of chickens' crop contents by season and age of bird.

\begin{tabular}{|c|c|c|c|c|c|c|}
\hline & \multicolumn{4}{|c|}{ Season } & \multicolumn{2}{|c|}{ Age of bird } \\
\hline Crop content (\%) & Early rainy & Late rainy & Early dry & Late dry & Layer & Grower \\
\hline Grains $^{1}$ & $29.82 \pm 2.12^{C}$ & $23.36 \pm 2.71^{\mathrm{C}}$ & $76.25 \pm 3.40^{b}$ & $56.35 \pm 2.16^{a}$ & $60.39 \pm 2.41^{\mathrm{a}}$ & $32.50 \pm 2.11^{b}$ \\
\hline Green/forages, $^{2}$ & $15.19 \pm 1.72^{\mathrm{a}}$ & $9.22 \pm 0.91^{b}$ & $3.64 \pm 0.13^{b}$ & $5.20 \pm 0.41^{b}$ & $8.80 \pm 0.14$ & $7.32 \pm 0.11$ \\
\hline Insects/worms $^{3}$ & $10.69 \pm 1.52^{\mathrm{a}}$ & $7.98 \pm 1.01^{a}$ & $2.15 \pm 0.41^{b}$ & $3.24 \pm 0.22^{b}$ & $7.98 \pm 0.12^{\mathrm{a}}$ & $4.05 \pm 0.22^{b}$ \\
\hline Kitchen wastes ${ }^{4}$ & $40.45 \pm 2.91^{a}$ & $37.92 \pm 2.53^{\mathrm{a}}$ & $9.22 \pm 0.90^{b}$ & $16.67 \pm 1.12^{b}$ & $34.19 \pm 2.22^{a}$ & $17.94 \pm 1.8^{b}$ \\
\hline Others $^{5}$ & $12.54 \pm 1.61^{a}$ & $14.08 \pm 1.62^{a}$ & $8.72 \pm 0.81^{b}$ & $18.55 \pm 1.63^{a}$ & $3.25 \pm 0.13^{b}$ & $23.70 \pm 2.14^{\mathrm{a}}$ \\
\hline
\end{tabular}

$a ; b ; c=$ means with different superscripts within a row and factor are significantly different $(P<0.05)$.

$1 \quad$ - Whole paddy rice

2 - $\quad$ Grasses, green vegetable

3. - - $\quad$ Earthworm, grass hoppers

4. - - Cooked rice, potatoes

$5 . \quad-\quad$ - Melon seeds, pebbles

Table 2 presents the proximate composition of the chickens' crop contents by season and age of bird. Only ash, NFE and metabolizable energy $\mathrm{Kcal} / \mathrm{kg}$ showed significant $(P<0.05)$ variation between season and age of bird, but crude protein varied only between season and not age of bird, being slightly higher in the late dry season. All the other proximate 
compositions of the crop contents were unaffected by season and age of bird.

The calcium and phosphorus composition of the crop contents are presented in Table 3. There was no significant $(P>0.05)$ seasonal effect on the mineral

Table 2: Proximate composition of chicken's crop contents by season and age of bird

\begin{tabular}{|l|l|l|l|l|l|l|}
\hline & \multicolumn{3}{|c|}{ Season of year } & \multicolumn{2}{c|}{ Age of bird } \\
\hline $\begin{array}{l}\text { Proximate } \\
\text { composition } \\
(\%)\end{array}$ & Early rainy & Late rainy & Early dry & Late dry & Layer & \\
\hline Moisture & $5.91 \pm 0.91$ & $9.36 \pm 0.85$ & $9.88 \pm 1.36$ & $8.71 \pm 1.24$ & $8.65 \pm 1.09$ & $8.28 \pm 1.06$ \\
\hline Dry matter & $94.09 \pm 0.91$ & $90.64 \pm 0.85$ & $90.12 \pm 1.36$ & $91.29 \pm 1.24$ & $91.35 \pm 1.09$ & $91.72 \pm 1.06$ \\
\hline Crude protein & $12.07 \pm 2.34^{\mathrm{a}}$ & $11.31 \pm 2.6^{\mathrm{a}}$ & $12.77 \pm 1.10^{\mathrm{a}}$ & $10.94 \pm 1.68^{\mathrm{b}}$ & $11.32 \pm 2.09$ & $12.22 \pm 1.79$ \\
\hline Ether extract & $6.55 \pm 3.46$ & $5.12 \pm 1.62$ & $6.13 \pm 0.54$ & $5.63 \pm 2.29$ & $5.38 \pm 1.76$ & $6.09 \pm 2.19$ \\
\hline Crude fibre & $7.55 \pm 0.69$ & $7.15 \pm 0.32$ & $9.95 \pm 1.65$ & $8.91 \pm 0.96$ & $8.55 \pm 1.05$ & $8.23 \pm 0.76$ \\
\hline Ash free & $24.58 \pm 6.27^{\mathrm{a}}$ & $26.15 \pm 5.92^{\mathrm{a}}$ & $18.05 \pm 1.28^{\mathrm{b}}$ & $15.87 \pm 0.98^{\mathrm{b}}$ & $23.33 \pm 4.69^{\mathrm{a}}$ & $18.98 \pm 2.41^{\mathrm{b}}$ \\
\hline $\begin{array}{l}\text { Nitrogen } \\
\text { extract }\end{array}$ & $50.02 \pm 0.69^{\mathrm{b}}$ & $49.08 \pm 0.18^{\mathrm{b}}$ & $53.62 \pm 3.35^{\mathrm{a}}$ & $56.26 \pm 2.52^{\mathrm{a}}$ & $51.48 \pm 2.41^{\mathrm{b}}$ & $53.01 \pm 1.95^{\mathrm{a}}$ \\
\hline $\begin{array}{l}\text { Metabolizable } \\
\text { Energy kcal/kg }\end{array}$ & $2427 \pm 235^{\mathrm{b}}$ & $2430 \pm 216^{\mathrm{b}}$ & $2429 \pm 258^{\mathrm{b}}$ & $2596 \pm 278^{\mathrm{a}}$ & $2352 \pm 260^{\mathrm{b}}$ & $2598 \pm 250^{\mathrm{a}}$ \\
& & & & & & \\
\hline
\end{tabular}

$\mathrm{a} ; \mathrm{b}=\quad$ means with different superscripts within rows and factors are significantly different $(\mathrm{P}<0.05)$.

Table 3: Mineral composition of chickens crop content by season and age of birth

\begin{tabular}{|l|l|l|l|l|l|l|}
\hline & \multicolumn{3}{|c|}{ Season of year } & \multicolumn{2}{c|}{ Age of bird } \\
\hline $\begin{array}{l}\text { Mineral composition } \\
(\%)\end{array}$ & Early rainy & Late rainy & Early dry & Late dry & Layer & Grower \\
\hline Calcium & & & & & & \\
\hline Phosphorus & $1.12 \pm 0.32$ & $1.49 \pm 0.49$ & $1.17 \pm 0.18$ & $0.72 \pm 0.15$ & $1.32 \pm 0.37^{\mathrm{a}}$ & $0.92 \pm 0.19^{\mathrm{b}}$ \\
\hline
\end{tabular}

There were no significant interaction effects for all parameters.

\section{DISCUSSION:}

From the visual observation of the crop contents of the local chickens, it could be seen that the major scavengeable feed resources available to the chicken in the study area include cereal grains, green forages, insects/worms and kitchen food wastes. The availability of these feed resources significantly $(P<0.05)$, varied with season depending on whether it is rainy (early and late) or dry (early or late) season. The observed highest grain content in the late dry season (January - March) could be attributed to the harvest of grains (late maize, rice, sorghum and millet) which takes place at this period in the community. Early planters of late maize and other cereals begin their harvest at the start of early dry season (October - December). This could explains the reason for higher grains in the crop contents in early dry season as compared to early and late rainy seasons. Gunarantne et al. (1993) and Dessie (1996) have previously observed that the crop contents of
( $\mathrm{Ca}$ and $\mathrm{P}$ ) contents of the crop. However, age of bird significantly affected the calcium and phosphorus of the crop contents.

scavenging chicken is affected by harvesting and planting periods. The significantly $(P<0.05)$ higher grains in the crop contents of layers as compared to that of growers may be a reflection of the preferential treatment given to the adult birds in grain supplementation by the local people. They believe that since the layers lay eggs or rear the chicks, they should have more feed. The difference could also be in the better foraging habits of layers, who are more experienced in foraging than the growers. The significant $(P<0.05)$ high grains in the contents of chicken crops in the late dry and early dry seasons are translated to significantly higher Nitrogen free extract (NFE) and metabolizable energy (ME) in the same seasons and bird types. This is expected since grains (concentrates) have high values of total digestible nutrients (TDN) and NFE.

The consumption of young sprouting shoots during the rainy season could have been responsible for the significant $(P<0.05)$ abundance of green forages in the crop contents during this season as compared to other seasons. Since the early rainy season follows the late dry season, many herb seeds germinate and grow into green forages. Similarly, insects/worms 
consumption was higher in the early and late rainy seasons than the early and late dry seasons for reasons that worms and insects are more abundant in the rainy season than the dry season. This greater consumption of insects and worms in these seasons could have accounted for higher crude protein levels of the crop contents from these seasons when compared to late dry season. The relatively high crude protein level of the crop contents in early dry season could be related to the harvest of leguminous crops such as soyabeans and other beans which takes place at this season.

The higher calcium content in the crop of layers than growers could be attributed to a selective feeding habit which is dependent upon the nutritional requirement of the bird types. It has been reported (Payne, 1990) that hens in lay have a higher requirement for calcium and therefore given a free choice feeding as in scavenging are more likely to pick calcium-rich feedstuffs than growers (Leeson and summers, 1991). Gunaratne et al (1993) and Mwalusanya et al (2002) reported similar findings in Sri Lanka and Tanzania respectively. In general, differences in the chemical compositions of crop contents between localities are due to differences in climate which determines the type and availability of feeds in the environment (Ologbobo, 1990).

It is noted in this study that the protein, calcium and phosphorus contents in the crop of scavenging local chicken were lower than the requirements of growers and adults (Payne, 1990).

Thus, the nutritional status of the scavenging local chicken in North Central Nigeria is below the requirement for optimum growth and egg production. Adequate feed supplementation based on composition of the available SFR in the seasons is necessary for improved productivity by the chicken types.

\section{REFERENCES}

AOAC (1990): Official methods of Analysis. $15^{\text {th }}$ Edn. (Washington, DC, Association of official Analytical chemists)
Dessie, T. (1996): Studies on village Poultry Production system in Central highlands of Ethiopia. M.sc Thesis, Swedish University of Agricultural Science Uppsala Sweden.

FAO, (1990): Soils bulletin 38/1. Soil and plant testing analysis, FAO Rome, 230pp.

Gunarantne, S.P; Chandresii, D. N; Mangalika, WAP and Roberts, J. A (1993). Feed Resource base for scavenging chickens in Sri Lanka. Tropical Animal health and production, 25: 249-257

Huchzemeyer, F.W. (1973): Free ranging hybrid chickens under African tribal conditions. Rhodesian Agricultural Journal. 70: 73-75.

Leeson, S and Summers, J. D. (1991) Commercial poultry Nutrition. $1^{\text {st }}$ edn.283 pp. (Guelph, Ontario, university books).

Mwalusanya, N, A; Katule, A. M; Mutayoba, S. K; Minga, U.M; Mtambo, M.M.A and Olsen, J.E (2002). Nutrient status of crop content of rural scavenging local chickens in Tanzania

Ologhobo, A. D (1990) Feed and feeding in extensive poultry production systems. Entwicklung landicherRaum, 24(4): 15-17

Payne W. J. A (1990). An Introduction to Animal Husbandry in the tropics, $4^{\text {th }}$ edn pp 684-744 (Essex and New York, Longman scientific and technical)

Roberts, J. A; and Gunarantne, S. P. (1992). The scavenging feed resource base for village chickens in a developing country, In: procedings of the $19^{\text {th }}$ world poultry congress. Amsterdam; the Netherkands. Vol.1 pp. 822-825.

SAS institute (199): SAS Statistics Users' guide. Statistical Analysis System, $5^{\text {th }}$ edition, (Carry, NC, SAS Institute Inc)

Sonaiya, E.B. (1997): ANRPD progress reports In: sustainable Rural poultry production in Africa. Ed Sonaiya, E.B. Proceeding of an International Workshop Addis Ababa Ethiopia. ANRPD. 134-143.

Wisemam, J. (1987). Feeding of Non-ruminant livestock. Butterworths. London, United Kingdom 9-13 